\title{
Implementation of Project-Based E-Learning in Courses Description Statistics During Covid-19
}

\author{
I Gde Wawan Sudatha ${ }^{1, *}$ Anak Agung Gede Agung ${ }^{1}$ \\ ${ }^{1}$ Education Technology Srudy Program, Universitas Pendidikan Ganesha, Singaraja, Indonesia \\ *Corresponding author.Email: igdewawans@undiksha.ac.id
}

\begin{abstract}
The rapid advancement of information and communication technology (ICT) has provided many changes and benefits for the world of education. During the Covid-19 pandemic, the presence of ICT has provided enormous benefits. One of the most important benefits is electronic-based learning (e-learning). In line with the electronic learning, there is also a change in the content of teaching materials, strategies, media, and evaluation of learning. The components were originally presented manually or in print are now presented digitally or electronically. To accommodate these changes, the Descriptive Statistics course in the Education Technology Department was designed by utilizing ICT and adopting a project-based learning model. For this reason, specifically this research aims to find out the significant difference in descriptive statistics learning outcomes between project-based learning project-based e-learning and project-based none-learning lessons. This research used a pre-experimental one group pretest-posttest design. The population of this research is the second semester students in the Education Technology Department, totaling 30 people consisting of 1 class. The data in this study were collected with observation sheets, questionnaires, and learning outcomes tests. Data on learning outcomes and student character were analyzed using descriptive statistics and one-way analysis of variance. Based on the results of the research and discussion, it can be concluded that there is a significant difference in descriptive statistics learning outcomes between project-based e-learning and project-based non-e-learning students in the Education Technology Department. That project-based e-learning has an influence on descriptive statistics learning outcomes for students of the Education Technology Department.
\end{abstract}

Keywords: E-Learning, Learning Outcomes, Project Based Learning.

\section{INTRODUCTION}

In the current situation of the COVID-19 pandemic, people are required to make various efforts in order to survive. Likewise in the world of education requires that the education and or learning process must continue because in any situation education must not be stopped. During this COVID-19 pandemic, the presence of ICT has provided enormous benefits. One of the most important benefits is electronic-based learning (elearning). In line with the electronic learning, there is also a change in the content of teaching materials, strategies, media, and evaluation of learning. In education, information and communication technology (ICT) is becoming increasingly crucial as traditional learning patterns shift toward more open and mediated modes of instruction [1].

The internet is a technology used to realize online learning. Haughey \& Anderson [2] reveal that there are three ways to create an internet-based learning system: web course, web-centric course, and web-enhanced course. Web course is the most common type of internetbased learning system. A web course is a complete use of the internet for educational purposes that takes place over a period of time. A web-centric course is one that takes use of the internet to combine distance learning with faceto-face training. It is a type of hybrid course (conventional). It is the use of the internet to assist in improving the quality of classroom-based learning that is referred to as the web augmented course model. When it comes to education, the internet's application is still mostly focused on the web-enhanced course paradigm. There are still only a few of educational institutions that use a web-based course approach as part of their curriculum.

Considering that the internet is very familiar among teenagers, it would be wiser if it is used by teenagers for their learning purposes as well as a medium of 
entertainment. However, the tendency that often occurs is where the internet is used more as an entertainment medium such as chatting on social media, watching videos, playing games, and so on. Students are still very minimal use of the internet for the sake of learning. If this phenomenon occurs continuously, students will prefer social media on the internet rather than choosing to study. This problem will have an impact on decreasing learning activities as well as student learning outcomes.

The term "e-learning" refers to the application of information and communication technology networks and technologies in the context of education [3]. Additionally, a variety of other terms are used to describe the concept of e-learning. The terms "online learning," "virtual learning," "network-based learning," and "webbased learning" are all used to refer to various forms of education. All of these words pertain to the learning process that makes use of information and communication technologies in general. The term elearning is more than just online learning, learning through cyberspace, network-based and web-based learning but e-learning is combining all learning activities, both individual or group work online or offline through a network or independently by computers and other electronic devices.

Clark [4] suggests 6 principles to optimize the use of e learning. The six principles concern the media elements in e-learning that Clark mentions, which are the basics of developing media in e-learning, namely: the principle of multimedia, the principle of contiguity, the principle of modality, the principle of redundancy, the principle of coherence, and the principle of personalization.

As the demands of the $21^{\text {st }}$ century require the development of aspects such as cooperation, respect for opinions, recognizing oneself and others, problemsolving skills and the like need to be grown in learning. To meet these demands, the learning strategy should also accommodate students to meet these demands. One of the innovative learning models that can be applied by lecturers is the project-based learning model.

Project-based learning (also known as project-based education) is a type of learning in which students work on a project. Project-based learning has been employed in a variety of sectors for many years, including medicine, engineering, education, economics, and business, to name a few. Problem-based learning is frequently confused with project-based learning, which is a common misconception. Although these two notions are related, they are not synonymous [5]. Despite the fact that both emphasize a student-centered learning environment, collaborative group work, and authentic evaluation methodologies, they differ in their approaches. Student participation in problem-solving activities, data collection activities, and data analysis activities are encouraged in problem-solving learning, whereas in project-based learning, students are encouraged to participate in design activities, formulate work, calculate work, carry out work, and evaluate results are encouraged [6].

In addition, Thomas [7] defines project-based learning as a methodology that organizes learning around projects in order to maximize effectiveness. Involving students in the creation of products or presentations and in problem solving, decision making, and investigative activities over long periods of time, projects are based on complex tasks or difficult questions or problems. They allow students to work independently over long periods of time and produce practical products or presentations. Some of the viewpoints expressed above lead to the conclusion that project-based learning is a systematic teaching model that actively engages students, encourages collaboration to build knowledge, and promotes skill development through complex tasks such as planning, designing, problem-solving, deciding on actions and communicating the outcomes of those actions and results (products).

When implementing project-based learning, the following five characteristics must be taken into consideration: centrality, driving question, constructive exploration, autonomy, and realism [7]. These five principles set project-based learning apart from problembased learning. As a result of project-based learning, teachers and students are encouraged to renounce the use of written assessments in favor of more authentic assessment alternatives. While understanding learning materials is essential, the emphasis in project-based learning is on applying knowledge and skills to realworld situations to solve problems. Students must not only comprehend the subject matter, but they must also be able to apply what they have learned in the classroom to the actual world.

Studying project-based eLearning in order to anticipate the problem of inappropriate internet use, inadequate face-to-face learning, and expectations of the 21st century was undertaken. Using the Moodle LMS, project-based learning is implemented online.

\section{METHOD}

Experimentation is the preferred method in this context. This study is characterized as a pre-experimental one-group pretest-posttest study since not all parameters (symptoms seen) and experimental circumstances can be closely monitored and controlled.

It is possible to categorize the many components in this experiment as follows: Learning outcomes are the dependent variable in this study. The learning outcome test score in this case is the pre-test score and the posttest score, and the independent variable in this study is the project-based e-learning model. 
The population for this study comprises of 30 2nd semester students from the Department of Education Technology, who were divided into one class. In order to acquire empirical results, the learning outcomes test method will be utilized to collect data in this study in order to gather data.

The one-way analysis of variance technique was used in this study to analyze the variance. The ANOVA is calculated with the assistance of the program's aid, which is the SPSS-PC 16.0 for Windows application. Throughout the study, all hypothesis testing was performed at a level of significance of $5 \%$.

\section{RESULT AND DISCUSSION}

\subsection{Result}

Research on the implementation of project-based elearning is carried out for one semester online or in a network (online). The observed variable is the student learning outcomes of the Education Technology Department, Faculty of Education, Undiksha in the Descriptive Statistics course.

Before testing the hypothesis using the t-test, the prerequisites are tested using: 1) normality test and 2) homogeneity test. Based on the normality test in the table above in the Kolmogorov-Smirnov(a) column, it shows that: 1) the pretest score data obtained sig 0.200 greater than the specified significance level of 0.05 so that the pretest score was normally distributed. Posttest data, each student obtained a sig, 0.001. The significance obtained is smaller than the 0.05 significance level so that the student's posttest data is declared not normally distributed. The test results Based on Mean show that for $\mathrm{Sig}=0.188$. If the significance level is 0.05 , then the Sig obtained is 0.188 which is greater than 0.05 . Thus, the learning outcomes data have homogeneous variants.

Based on the tests, only one prerequisite is met, namely the homogeneity of variance in the learning outcomes data, while the normality test on the posttest score has not been fulfilled. Thus, hypothesis testing using t-test cannot be carried out. Furthermore, hypothesis testing was carried out using non-parametric statistics in the form of the Wilcoxon test.

According to the Wilcoxon test results, Asymp. Sig (2-tailed) is worth 0.000 . Because 0.000 is less than 0.05 , $\mathrm{Ha}$ is accepted while $\mathrm{H} 0$ is refused. This suggests there is a substantial difference in descriptive statistics learning outcomes before and after project-based e-learning implementation.

\subsection{Discussion}

This study compares the learning outcomes of students using project-based e-learning vs non-elearning. As a result, project-based e-learning students learn differently from non-e-learning students. A study by Febrianita [8] found that students who study using project-based blended learning have higher outcomes than students who study using direct learning models. project-based blended learning Similar findings were observed by Putri et al. [9], who said that project-based learning improves student outcomes compared to conventional learning. Similar to Rajan et al. [10], this study found that project-based learning can improve students' motivation and critical thinking more than traditional learning. Similarly, Safitri and Suparwoto [11] found that project-based e-learning helps students build creative thinking skills while learning physics.

Project-based e-learning combines project-based learning and e-learning approaches. Project-based elearning allows students to enhance their knowledge and abilities by focusing on obstacles and producing products that are combined with e-learning approaches. These real-life themes include concepts that students should grasp. To take stuff, demonstrate knowledge, and apply it in the actual world. Arizona et al. [12] concluded that project-based learning is one of the learning strategies that can maximize online learning. This type of learning allows pupils to learn more deeply while boosting their results.

Project-based learning allows students to study material in ways that matter to them [13]. Using a projectbased e-learning strategy in small groups allows students to deal with various opinions. Students must evaluate current opinions, clarify facts, select the best alternative solutions, and choose the best response for the given situation. Group conversations help students develop critical thinking skills.

\section{CONCLUSSION}

Based on the findings of this study and the discussion that follows, it is possible to conclude that there is a significant difference in descriptive statistics learning outcomes between students in the Educational Technology Department who participate in project-based e-learning and students who participate in non-e-learning project-based projects. According to the findings, project-based e-learning has an effect on descriptive statistics learning outcomes for students in the Education Technology Department.

\section{AUTHORS' CONTRIBUTIONS}

The author of this article contributes to the development of design instructional, learning outcome instruments test, and article writing.

\section{ACKNOWLEDGMENTS}

The author would like to thank all the support from the Universitas Pendidikan Ganesha so that the resulting research processes and products can be used in learning. 


\section{REFERENCES}

[1] Rusman, D. Kurniawan, and C. Riyana, Pembelajaran Berbasis Teknologi Informasi dan Komunikasi: Mengembangkan Profesionalisme Guru. Jakarta: PT Rajagrafindo Persada, 2011.

[2] M. Haughey and T. Anderson, Networked Learning: The pedagogy of the Internet. Montreal: Cheneliere/McGraw-Hill, 1998.

[3] S. Naidu, E-Learning A Guidebook of Principles, Procedure and Practice. New Delhi: Cemca, 2006.

[4] R. C. Clark, Six Principles of Effective e-Learning. Orlando: The Elearning Guild, 2002.

[5] R. M. Capraro and S. W. Slough, Project-based learning: An integrated science, technology, engineering, and mathematics (STEM) approach. Texas: Sense Publishers, 2009.

[6] N. L. Maxwell, Y. Bellisimo, and J. Mergendoller, "Problem-based learning: Modifying the medical school model for teaching high school economics," 1999. http://www.bie.org.

[7] J. W. Thomas, A review of research on projectbased learning. California: The Autodesk Foundation, 2000.

[8] N. K. I. Febrianita, "Keefektifan Blended Learning Berbasis Project dan Gaya Belajar Terhadap Keterampilan Berpikir Kritis Dalam Pembelajaran Dasar Desain Grafis Pada Siswa SMK," Program Pascasarjana Universitas Pendidikan Ganesha, Singaraja, 2019.

[9] I. N. A. Putri, N. Fadiawatia, and M. M. F. Syamsuria, "Using Projects-Based Learning in Improving Students' Critical Thinking Skills to Recycle Waste Cooking Oil," Int. J. Chem. Educ. Res., vol. 3, no. 1, pp. 23-28, 2019.

[10] K. P. Rajan, A. Gopanna, and S. P. Thomas, "A Project Based Learning (PBL) Approach Involving Pet Recycling in Chemical Engineering Education," Recycling, vol. 4, no. 10, pp. 1-16, 2019.

[11] A. D. Safitri and Suparwoto, "Enhancing Senior High School Students' Creative Thinking Skills using Project Based E-1 Learning," J. Phys., pp. 1$6,2018$.

[12] K. Arizona, Z. Abidin, and R. Rumansyah, "Pembelajaran Online Berbasis Proyek Salah Satu Solusi Kegiatan Belajar Mengajar di Tengah Pandemi Covid-19," J. Ilm. Profesi Pendidik., vol. 5, no. 1, pp. 64-70, 2020.

[13] M. Wena, Strategi Pembelajaran Inovatif Kontemporer. Jakarta: Bumi Aksara, 2011. 